\title{
Gastrointestinal parasite infection of the Gray mouse lemur (Microcebus murinus) in the littoral forest of Mandena, Madagascar: Effects of forest fragmentation and degradation
}

\author{
Brigitte M. Raharivololona' and Jörg U. Ganzhorn"
}

Correspondence:

Brigitte M. Raharivololona

Département d'Anthropologie et de Biologie Évolutive,Université d'Antananarivo, Antananarivo 101, Madagascar

E-mail:raharivololonabrigitte@yahoo.fr

\begin{abstract}
Faecal material from 169 individuals of Microcebus murinus living in five littoral forest fragments was analyzed for gastrointestinal parasites. The fragments differed in size and forest quality. Gastrointestinal parasite infection of $M$. murinus was characterised using parasite species richness, the prevalence of parasites, and the intensity of infection expressed as the number of parasite eggs, larvae and cysts per gram of faeces. For this, a modification of the McMaster flotation egg counting technique was applied to analyze egg shedding. We recorded nine gastrointestinal parasite species in faecal samples of Microcebus murinus. In good quality forest lemurs from a smaller fragment had higher prevalences and intensities of infection of gastrointestinal nematodes and protozoans than animals from a larger forest fragment. In large forests, excretion of eggs from Ascarididae and tapeworms was higher in a degraded forest fragment than in a good quality forest fragment. This situation was reversed in small forest fragments with fewer eggs of Suburula nematodes and protozoans shed by lemurs in the degraded fragment than by lemurs from the good quality fragment. Our analyses are hampered by the fact that we had only one forest fragment per type of treatment. Keeping this limitation in mind, the results are consistent with other studies and indicate that forest degradation and fragmentation have marked effects on the level of parasitism of Madagascar's lemurs.
\end{abstract}

\section{RÉSUMÉ}

Des matières fécales de 169 individus de Microcebus murinus vivant dans cinq fragments de forêt littorale du sud de Madagascar ont été analysées par la méthode modifiée de flottaison de McMaster. Ces animaux avaient été capturés entre avril 2003 et octobre 2005. Les fragments de forêt diffèrent entre eux par la taille et le degré de dégradation. Pour étudier l'impact de la fragmentation et de la dégradation de la forêt sur l'infestation parasitaire de cette espèce de lémurien, trois critères ont été évalués qui sont le nombre d'espèces de parasite, la prévalence et l'intensité de l'infestation. Les fragments ayant des tailles différentes mais montrant un même type de dégradation ont fait l'objet d'une comparaison au même titre que des fragments présentant un même degré de dégradation mais de mêmes tailles. Neuf espèces de parasites gastro - intestinaux ont été recensées chez Microcebus murinus de la forêt de Mandena dont six nématodes avec une espèce non-identifiée de la famille des Ascarididae et de l'ordre des Strongylida, Trichuris sp., deux espèces d'Oxyuridae dont I'une est du genre Lemuricola et une autre qui n'est pas encore identifiée, subulura sp., deux cestodes appartenant au genre Hymenolepis et un protozoaire de l'ordre des Coccidia. La fragmentation et la dégradation de la forêt de Mandena affectent le parasitisme de cette espèce de lémurien.

Les deux tendances qui ressortent de cette étude sont, d'une part, une augmentation de l'intensité et de la prévalence des parasites gastro-intestinaux de Microcebus murinus dans les plus petits fragments forestiers et d'autre part, une augmentation qui semble être en relation avec le degré de dégradation de la forêt dans les plus grands fragments. L'augmentation du nombre d'espèces de parasites avec la taille des fragments peut être une conséquence de la taille des fragments ou du nombre d'animaux échantillonnés. Dans les grands fragments, les microcèbes sont plus souvent infestés par les deux espèces de cestode lorsqu'ils sont dans des forêts dégradées que dans les fragments plus ou moins intacts. Dans les plus grandes parcelles forestières, la prévalence et l'intensité de l'infestation parasitaire sont plus élevées chez les microcèbes vivant dans les fragments très dégradés. Ce fait pourrait être dû à la réduction ou la perte de I'habitat associée à I'organisation sociale de l'animal car $M$. murinus dort en groupe pendant le jour, de sorte qu'une réduction de son habitat pourrait favoriser une augmentation des contacts interindividuels et la transmission de parasites, bien que l'infestation des microcèbes n'était pas liée à la densité des hôtes d'une manière significative. En connaissant l'effet néfaste des parasites, cette étude contribuerait à l'amélioration de la conservation de la biodiversité en relation avec les risques et les bénéfices des activités d'exploitation et de gestion de l'écosystème.

KEY WORDS: Lemurs, primates, gastrointestinal parasites, fragmentation, degradation.

MOTS CLEF : lémuriens, primates, parasites gastro-intestinaux, fragmentation, dégradation. 


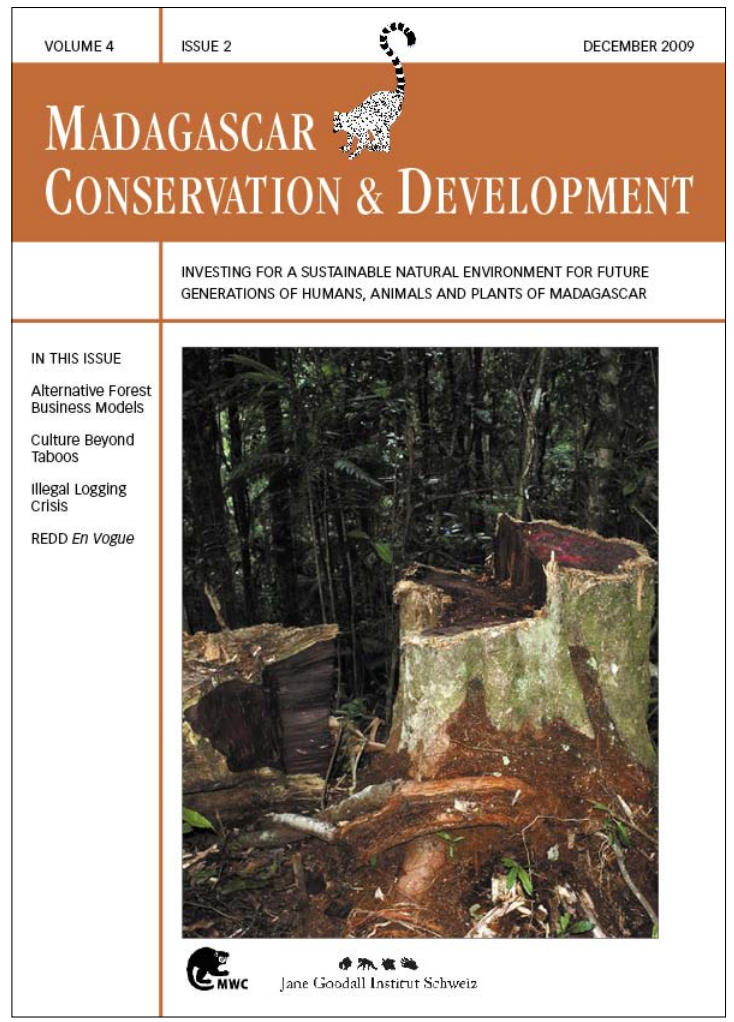

Madagascar Conservation \& Development is the journal of Madagascar Wildlife Conservation (MWC) and the Jane Goodall Institute (JGI Switzerland). It is produced in these institutions' own responsibility.

All the Issues and articles are freely available at http://www.mwc-info.net/en/services/journal.htm

Contact Journal MCD

info@journalmcd.net for general inquiries MCD funding@journalmcd.net for supporting the journal

Journal Madagascar Conservation \& Development Institute and Museum of Anthropology University of Zurich

Winterthurerstrasse 190

$\mathrm{CH}-8057$ Zurich, Switzerland

contact@mwc-info.net for general inquiries

Postfach 2701

CH-8021 Zürich, Switzerland

Logement 11, Cité Andohaniato

Antananarivo 101, Madagascar

info@janegoodall.ch for general inquiries JG

$2 \pi \approx$

Jane Goodall Institut Schweiz
Jane Goodall Institute Schweiz

Postfach 2807

8033 Zürich

switzerland 


\section{INTRODUCTION}

The outstanding biodiversity of Madagascar is threatened by the destruction of native habitats such as forest fragmentation, degradation and subsequent erosion (Mittermeier et al. 2004, Elmqvist et al. 2007, Harper et al. 2007, Allnutt et al. 2008). In addition to the destruction of habitat, native species can be affected by the transmission of disease (Wallis and Lee 1999, Smith et al. 2009). The effects of changes in the pathways of parasite transmission, changes in parasite prevalence in modified habitats, and the effects of newly introduced parasites on native species have received little attention in Madagascar even though there are signs of disease transmission from introduced to native species (Begon et al. 1999, Duplantier and Duchemin 2003, Duplantier et al. 2003), which might lead to population declines of the endemics (Goodman 1995). Host populations can be affected by parasites through a reduction in population growth (Hudson et al. 1998, Hochachka and Dhondt 2000), through reduced survival and decreased physical fitness (Chandra and Newberne 1977, Boyce 1990, Dobson and Hudson 1992, Hudson et al. 1992, Coop and Holmes 1996), or through reduced birth rates due to malformations and abortion (Chandra and Newberne 1977, Despommier et al. 1995).

Studies on gastrointestinal parasites of primates have focussed on haplorhine primates (Appleton et al. 1986, Eley et al. 1989, McGrew et al. 1989, Stoner 1996, Stuart et al. 1990, 1998, Müller-Graf et al. 1997, Ashford et al. 1990, 2000, Lilly et al. 2002, Hahn et al. 2003, Gillespie et al. 2004, 2005, Chapman and Huffman 2009). Prosimians' gastrointestinal parasites are less well studied. Some studies have been conducted on lemur parasites, but most studies have focussed on inventories and morphological descriptions (e.g., Chabaud and Choquet 1955, Chabaud and Brygoo 1956, Chabaud and Petter 1958, 1959, Chabaud et al. 1961a,b, 1964, 1965, Petter et al. 1972, Hugot et al. 1995, 1996, Randriamiadamanana 1998, Hugot and Baylac 2007, Rasambainarivo 2008). Few studies were based on animals in their natural habitat (Junge and Louis 2002, 2005, 2007, Junge and Sauther 2006). Schwitzer et al. (In press) compared the prevalence of gastrointestinal parasites in Eulemur flavifrons in primary and secondary forest in the Sahamalaza National Park of northwestern Madagascar. In their study, a higher percentage of lemurs were infected with gastrointestinal parasites in secondary than in primary forest. Irwin and Raharison (Submitted) summarize the current knowledge about endoparasites of lemurs in Madagascar. Raharivololona $(2006,2009)$ extends the previous knowledge on gastrointestinal parasites by data from a long-term study on Microcebus murinus from the littoral forest fragments of Mandena with additional information on the occurrence of these parasites in sympatric lemurs and other small mammals (Raharivololona et al. 2007). In these forests, Schad et al. $(2004,2005)$ found the highest parasite loads in mouse lemurs living in one of the smaller fragments. They were able to correlate the occurrence of parasites with specific alleles of the major histocompatibility complex. More recently Wright et al. (2009) analyzed the ectoparasite communities of Propithecus edwardsi in Ranomafana National Park. Ectoparasite infestation did not change much between primary and more degraded rain forest but changed significantly between the cool and the hot season.

Fragmentation of primary forests, degradation of habitats and conversion into anthropogenic landscapes is a rapid process in Madagascar (see references cited above) While the protected area system has been extended over the last few years in the wake of the Durban vision, the established protected areas risk to become more and more isolated due to development activities and climate change (Burney et al. 2004, Bodin et al. 2006, Hannah et al. 2008). Animals will then remain in the isolated fragments or have to use secondary and degraded corridors to move between primary forest sites. This situation leads to an increase in edge effects and possible disease transmission by non-forest or introduced species, such as rats, humans and other species associated with human activities. The question then is how animals are affected by fragmentation and degradation. To gain more insights into possible effects of these processes on lemurs we extend previous reports on the ecological context of the occurrence and intensity of infection by gastrointestinal parasites of Microcebus murinus living under different environmental conditions in the humid littoral forest of southeastern Madagascar (Schad et al. 2004, 2005, Raharivololona et al. 2007, Raharivololona and Ganzhorn In press, Ganzhorn et al. In press). In particular, we address the questions:

- $\quad$ Are parasite loads of Microcebus murinus related to host density?

- Do parasite loads differ in forest fragments of similar forest quality but of different size?

- Do parasite loads differ in forest fragments of similar size but different degrees of degradation?

\section{METHODS}

STUDY SPECIES. Microcebus murinus, the Gray mouse lemur, is a small (average $60 \mathrm{~g}$ ) nocturnal and omnivorous lemur. It is widespread and not considered endangered. Its diet consists of insects, fruit, flowers, and leaves. They also eat sap, gum, secretions from homopteran larvae, and small vertebrates such as frogs, geckos, and chameleons. This lemur forages alone but congregates at daytime sleeping sites. The species is arboreal, polygynous, and distributed throughout western, southern, and southeastern Madagascar (Figure 1). They occur in primary, secondary, and disturbed forest habitats (Martin 1972, Petter et al. 1977, Lahann et al. 2006, Mittermeier et al. 2008).

STUDY SITE. The study was carried out in fragments M5, M13, M15, M16, and M20 of the littoral forest of Mandena, $12 \mathrm{~km}$ northeast of Tolagnaro at sites ranging in altitude from 0 to $20 \mathrm{~m}$ (Figure 1). Annual rainfall is about 1,600 $\mathrm{mm}$ (Vincelette et al. 2007a). The forest fragments differed in size and their degree of degradation. Vincelette et al. (2007b) measured the state of a given forest fragments in $50 \mathrm{~m}$ intervals along $50 \mathrm{~m}$ wide transects in each forest block. If the block was too narrow to include more than one transect, a single line was drawn with transects shorter than $50 \mathrm{~m}$ and perpendicular to the main line. The following data were obtained at each sampling position spaced $50 \mathrm{~m}$ apart and within the $50 \times 50 \mathrm{~m}$ grid: General condition of the forest; signs of cutting (stumps) and fires; openings and agricultural areas; and observations of the vertical structure of the forest canopy level (upper, intermediary, or lower). Finally, the field observer evaluated, in a diagrammatic way, the canopy cover at the sampling position. The observer estimated the percentage of surface area occupied by the tree canopy within a $20 \mathrm{~m}$ radius of the sampling site. In cases where the canopy was continuous, represent- 


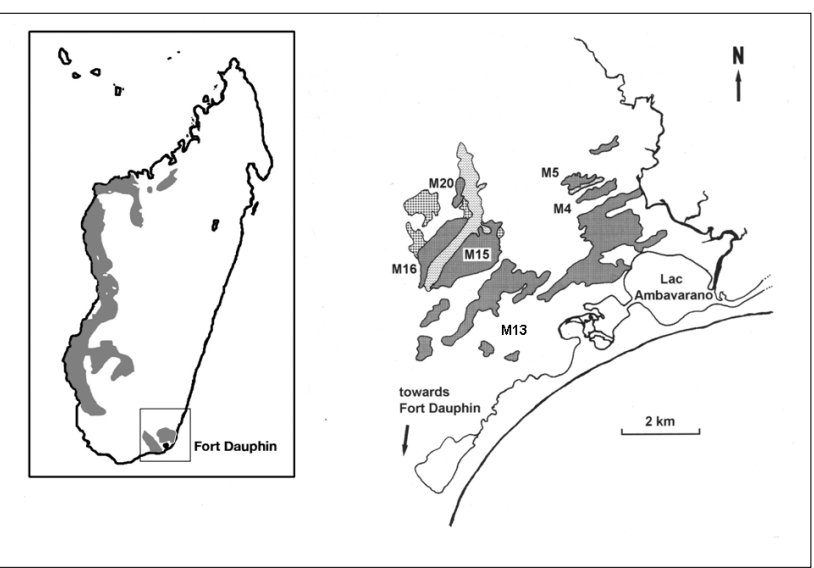

FIGURE 1. Location of study areas in the Tolagnaro region. The forest remnants are numbered and shown as dark shading. Eucalyptus plantations are crosshatched. Swamps with bordering Melaleuca (introduced) are marked with curved lines. The grey area in the insert map marks the distribution of Microcebus murinus on Madagascar (insert map from Ramon Hernando Orozco / Conservation International; detailed map modified from Ramanamanjato and Ganzhorn 2001).

ing $100 \%$ cover, this corresponds to a littoral forest in good condition. The percentage canopy cover was then categorized in five classes of forest degradation (Vincelette et al. 2007b; Table 1). Additional measures to describe the vertical stratification of the forest blocks and schematic drawings are presented in Ganzhorn et al. (2007), Rabenantoandro et al. (2007) and Rasolofoharivelo (2007).

Fragments were classified as: M20: small and degraded / low quality forest; M13: large and degraded / low quality forest; M5: small and good quality forest (less degraded than M20; M20 underwent continuous degradation over the course of the study); and M15: large and good quality forest (less degraded than M13). Except for fragment M16, the state of the forest fluctuated only within a given category of degradation during the study period. The fragment M16 underwent degradation and subsequent recovery over the course of the study. In the previous analyses M16 had been combined with M15 as the two fragments can be considered to be contiguous even though a swamp separates them. However, we did record marked changes in the population density of $M$. murinus in M16 over time, which might have been linked to the degradation of M16 (but not in M15). Since the consequences of the ephemeral degradation for parasite infections are unclear, we did not consider M16 in the present analyses. However, the descriptive data of M16 are listed for comparison. M16 resembles M15 with respect to parasite prevalence and the intensity of infection. Therefore, pooling of
M16 with M15 would have strengthened the results and conclusions based on M15 (Table 1).

ANIMAL CAPTURE. Small mammals were captured with Tomahawk and Sherman (Tomahawk Live Trap CO. Tomahawk, Wl; H. B. Sherman Traps, Inc., Tallahassee, FL) live traps using standard procedures at permanent study sites set up in different forest fragments of Mandena (Ramanamanjato and Ganzhorn 2001). Traps baited with banana were set for four nights per month at 80 or 100 localities per fragment between April 2003 and October 2005. Trapping sessions rotated between fragments systematically to avoid effects of seasonality and to achieve similar trapping effort at each locality in each month. Our own trapping was discontinued from January to April when females had babies. Additional faecal samples (29 samples from M15, M16 and M20 of the 169 samples) were provided from animals caught by Petra Lahann, Nina Rüdel, Jörg Schüller and Björn Siemers. The samples collected by Petra Lahann had been collected in M15 between November 2003 and March 2004. Traps were checked in the morning. Trapped animals were released in bags to be sexed, measured, weighed, and marked permanently with subdermal transponders. Animals were released at the locality where they had been captured at the beginning of the night. Trapping and handling was authorized by permits issued by the Ministère de I'Environnement, des Eaux et Forêts Malgache.

Population densities (individuals per hectare) were measured as the number of animals caught per site by the size of the permanent study site. These densities fluctuated over the years. The low number of captures does not allow applying density calculations based on mark-recapture data. Population density estimates vary between 3 and 21 animals per hectare and increased from M5 - M13 - M20 - M15 - M16 (Ganzhorn et al. 2007). Total population size of the host was calculated by multiplying density estimated by the size of the forest fragment.

FAECAL SAMPLING AND ANALYSES. Fresh faeces were

collected from handling bags or traps and stored in vials containing $4 \%$ formalin (traps and handling bags were cleaned after use). A modification of the McMaster flotation egg counting technique (Sloss et al. 1994) was applied to analyze egg shedding which has been considered a valid method of evaluating worm burden in several studies (e.g., Gulland et al. 1993, Stear et al. 1995, Paterson et al. 1998, Coltman et al. 1999, Cassinello et al. 2001, Schwensow et al. 2007). For this, $300 \mathrm{mg}$ of faeces were triturated in a beaker with $3 \mathrm{ml}$ of a saturated potassium iodide solution (KI) with a specific weight of $1.5 \mathrm{~g} / \mathrm{ml}$. The mixture was poured through a tea strainer to eliminate non-digested large particles. The residue in

TABLE 1. Characteristics of fragments of the littoral forest of Mandena (as of the year 2000), trapping effort and capture results.

\begin{tabular}{|l|l|l|l|l|l|}
\hline \multirow{2}{*}{} & \multicolumn{5}{|c|}{ Fragment } \\
\cline { 2 - 6 } & M5 & M13 & M15 & M16 & M20 \\
\hline Size (ha) & 28 & 80 & 113 & 75 & 15 \\
\hline Forest quality & $51-70 \%$ & $<20 \%$ & $51-70 \%$ & $21-50 \%$ & $21-50 \%$ \\
\hline Number of trapnights & Good & Poor & Good & Intermediate & Poor \\
\hline Number of faecal samples & 3,300 & 4,200 & 2,347 & 3,800 & 2,800 \\
\hline Number of M. murinus (without recaptures) & 28 & 64 & 82 & 174 & 79 \\
\hline Density of M. murinus (ind./ha) & 14 & 24 & 54 & 47 & 427 \\
\hline
\end{tabular}


the tea strainer was washed with $1 \mathrm{ml}$ of $\mathrm{KI}$. The suspension was filled to a volume of $4.5 \mathrm{ml}$ with the $\mathrm{KI}$ solution, stirred again and transferred to both chambers of a McMaster counting chamber with a pipette. The slide was transferred to a microscope and left alone for five minutes before examining. During this time, eggs, larvae and cysts float to the surface of the McMaster counting chambers. The slide was then examined with $100 \mathrm{x}$ and $400 x$ magnification to identify and count all eggs, larvae and oocysts inside the ruled squares. This method was developed by Meyer-Lucht (2003) and has been applied successfully in a number of other studies (e.g., Meyer-Lucht and Sommer 2005, Schad et al. 2005). The procedures for parasite identification have been described previously (Raharivololona 2006, 2009). The assignment of eggs and larvae to some of the species listed in Table 2 has been verified by comparisons with adult parasites found in the digestive tract (Raharivololona 2009).

The analyses were based on the prevalence (= percentage of infected Microcebus murinus) of different nematode morphotypes in a population and the faecal egg count (FEC) value as measurements of the intensity of the parasite burden. For consistency with our previous papers we define FEC as the number of eggs and larvae found in one gram of faeces of one individual. This definition deviates from the generally accepted term, which includes only eggs. It is obtained by multiplying the number of eggs and larvae counted in the two chambers of Mc Master's cell by 50 (Euzéby 1981). Since M. murinus could be infested with parasites from other animals (such as from rats which share all parasites found in M. murinus [Raharivololona et al. 2007]) or some of the parasites excreted by $M$. murinus could be parasites from their invertebrate prey, precautions were taken to increase the probability that the parasites described were actual parasites of $M$. murinus. For this, some individuals of $M$. murinus were kept for four days in quarantine. Faecal samples were collected each morning and analyzed for parasites. Food passage time was investigated with markers and determined to be below 24 hours in all cases. Therefore all parasites found in the faeces of these animals after the second night were assumed to be genuine parasites of M. murinus and not temporary parasites from prey or accidental infections (Raharivololona 2009).

STATISTICS. For the present analyses each individual

Microcebus murinus was used only once. For the quantification of parasite loads we used the faecal sample collected at the first capture of the animal. Data from recaptures were not considered for two reasons: First, most recaptures occurred within a single 4 -night trapping session. Since traps were baited with banana and animals were fed banana while held in the traps, faeces consisted almost exclusively of banana the night after an animal had been caught. If an animal had been caught in 1-2 day intervals, the faeces were again different. Second, statistics would have been further complicated by varying recaptures of individuals in other months (with or without recaptures within these months). We are aware that we might lose information by not considering the data from the various recaptures, but the quality of data would not be the same for all data points, regardless of what kind of nested analyses we would apply. If a parasite species was not detected in the first sample, but was found later, it was not included in the present analyses. This approach matches the screening for para- sites in most primate studies where repeated captures of the same individuals is not possible.

since data deviated from normality we applied nonparametric statistics and restricted the analyses to single factor comparisons. For the analyses of the effects of fragment size, fragments were matched by the degree of degradation. For the analyses of the effect of degradation, fragments were matched by their size.

The statistical approach is a little bit misleading as we analyse data from four forest fragments, and use a series of pair-wise comparisons to compare pairs of fragments. Thus, in a rigorous statistical way, sample size equals 1 for each treatment. While the fragments vary in strategic ways (e.g. small degraded versus large degraded), any differences described in these pair-wise comparisons and linked to the variables 'forest size' and 'forest degradation' may be from the postulated source (e.g. fragment size) but could be due to something else entirely. Thus, the results have to be considered as 'indications' of possible effects of size and disturbance, but further study are necessary to verify this more directly.

\section{RESULTS}

In 16,447 trap nights we caught 169 individuals of Microcebus murinus in the five littoral forest fragments of Mandena (Table 1). These animals were infected with a total of nine gastrointestinal parasite species: Eight helminth species and one protozoan. The helminths included six nematodes: One species of Ascarididae and one of the order Strongylida, Trichuris sp., two species of Oxyuridae (Lemuricola sp. and one non-identified species), Subulura sp., and two cestodes (Platyhelminthes, genus Hymenolepis). The protozoan was a member of the Coccidia (Table 2). We consider all of these forms true parasites of M. murinus.

PARASITE LOADS AND HOST DENSITY. Though statistical

analyses are hampered by the low number of fragments, the number of different parasite species found seems to increase with the number of individuals captured, but this trend was not significant (Tables 1, 2). Neither parasite prevalence nor the intensity of infection was correlated significantly with the density of Microcebus murinus according to Spearman rank correlations (Tables 1, 3, 4).

Subsequently we summarize the results of the pair-wise comparisons of the different aspects of parasite loads between fragments of different size and forest quality. The data and the results of the statistical comparisons are listed in Tables 3 and 4. Significant differences between fragments are highlighted in the tables and described in the text. Non-significant results are listed in the tables but not described in detail in the text.

EFFECT OF FRAGMENT SIZE IN GOOD QUALITY FOREST

FRAGMENTS. The effect of forest and population size on the parasite load of Microcebus murinus was compared between the two good quality fragments M5 (small) and M15 (large).

Parasite species richness: On average, individual Microcebus murinus from the small fragment M5 harbor more parasite species than animals from the large fragment M15 (Mann Whitney U test: $\mathrm{Z}=2.25, \mathrm{p}<0.05$; Figure 2).

Prevalence of parasites: Nematodes occurred in a higher percentage of Microcebus murinus individuals in M5 than in M15. This difference was not significant if based on M15 alone $\left(X^{2}=3.16\right.$, $\mathrm{df}=1,0.05<p<0.1)$, but was significant if data from M16 were included $\left(X^{2}=4.37, d f=1, p<0.05\right)$. On a specific level, the preva- 
TABLE 2. Species of gastrointestinal parasites of Microcebus murinus in different littoral forest fragments (+: present; -: absent).

\begin{tabular}{|c|c|c|c|c|c|}
\hline & \multicolumn{5}{|c|}{ Fragment } \\
\hline & M5 & M13 & M15 & M16 & M20 \\
\hline Size (ha) & 28 & 80 & 113 & 75 & 15 \\
\hline Forest quality & Good & Poor & Good & Intermediate & Poor \\
\hline Number of $M$. murinus captured & 14 & 24 & 54 & 47 & 30 \\
\hline \multicolumn{6}{|l|}{ Nemathelminthes } \\
\hline \multicolumn{6}{|l|}{ Ascarididae } \\
\hline Ascarididae species & + & + & + & + & + \\
\hline Subulura sp. & + & + & + & + & + \\
\hline \multicolumn{6}{|l|}{ Strongylida } \\
\hline Strongylida species & - & - & + & + & + \\
\hline \multicolumn{6}{|l|}{ Trichuridae } \\
\hline Trichuris sp. & + & - & + & - & + \\
\hline \multicolumn{6}{|l|}{ Oxyuridae } \\
\hline Lemuricola sp. & - & + & + & - & + \\
\hline Oxyuridae species & + & - & + & + & + \\
\hline Total number of nematode species & 4 & 3 & 6 & 4 & 6 \\
\hline \multicolumn{6}{|l|}{ Plathelminthes } \\
\hline \multicolumn{6}{|l|}{ Cestoda } \\
\hline \multicolumn{6}{|l|}{ Hymenolepididae } \\
\hline Hymenolepis sp1 & + & + & + & + & + \\
\hline Hymenolepis sp2 & - & + & + & + & + \\
\hline Total number of cestode species & 1 & 2 & 2 & 2 & 2 \\
\hline Protozoa (Coccidia) & + & + & + & + & + \\
\hline Total number of all parasite species & 6 & 6 & 9 & 7 & 9 \\
\hline
\end{tabular}

TABLE 3. Prevalence (\%) of different gastrointestinal parasite species in Microcebus murinus in five littoral forest fragments. Differences between fragments were evaluated with Chi-Square and Fisher's Exact tests; for Chi-square tests Chi-square values and significance categories are listed; for Fisher's Exact test only $\mathrm{p}$-values are listed: * $\mathrm{p}<0.05 ; * * \mathrm{p}<0.01$

\begin{tabular}{|c|c|c|c|c|c|c|c|c|c|}
\hline & \multicolumn{5}{|c|}{ Fragment } & \multicolumn{4}{|c|}{ Comparison } \\
\hline & M5 & M13 & M15 & M16 & M20 & M5 - M15 & $\mathrm{M} 20-\mathrm{M} 13$ & M15 - M13 & M5- M20 \\
\hline Number of $M$. murinus & 14 & 24 & 54 & 47 & 30 & & & & \\
\hline \multicolumn{10}{|l|}{ Nemathelminthes } \\
\hline \multicolumn{10}{|l|}{ Ascarididae } \\
\hline Ascarididae species & 21.4 & 37.5 & 11.1 & 17 & 30 & 0.38 & $X^{2}=0.34$ & $0.01 *$ & 0.72 \\
\hline Subulura sp. & 71.4 & 20.8 & 37 & 44.7 & 23.3 & $X^{2}=4.43^{*}$ & $x^{2}=0.05$ & $x^{2}=2.00$ & $x^{2}=9.31 * *$ \\
\hline \multicolumn{10}{|l|}{ Strongylida } \\
\hline Strongylida species & 0 & 0 & 11.1 & 10.6 & 6.7 & 0.33 & 0.5 & 0.17 & 1 \\
\hline \multicolumn{10}{|l|}{ Trichuridae } \\
\hline Trichuris sp. & 14.2 & 0 & 7.4 & 0 & 10 & 0.6 & 0.25 & 0.31 & 0.65 \\
\hline \multicolumn{10}{|l|}{ Oxyuridae } \\
\hline Lemuricola sp. & 0 & 4.2 & 9.3 & 0 & 3.3 & 0.58 & 1 & 0.66 & 1 \\
\hline Oxyuridae species & 7.14 & 0 & 3.7 & 8.5 & 20 & 0.51 & $0.02 *$ & 1 & 0.4 \\
\hline Prevalence of all nematodes & 85.7 & 45.8 & 50 & 57.5 & 56.7 & $x^{2}=3.16^{*}$ & $x^{2}=0.63$ & $x^{2}=0.12$ & 0.09 \\
\hline \multicolumn{10}{|l|}{ Plathelminthes } \\
\hline \multicolumn{10}{|l|}{ Cestoda } \\
\hline \multicolumn{10}{|l|}{ Hymenolepididae } \\
\hline Hymenolepis sp1 & 21.4 & 33.3 & 7.4 & 38.3 & 26.7 & 0.15 & $X 2=0.28$ & $0.006 * *$ & 1 \\
\hline Hymenolepis sp2 & 0 & 8.3 & 1.9 & 2.1 & 6.7 & 1 & 1 & 0.22 & 1 \\
\hline Prevalence of all cestodes & 21.4 & 37.5 & 7.4 & 40.4 & 33.3 & 0.15 & $x^{2}=0.10$ & $0.002 * *$ & 0.5 \\
\hline Protozoa (Coccidia) & 85.7 & 58.3 & 44.4 & 46.8 & 40 & $X^{2}=5.18^{*}$ & $X^{2}=1.80$ & $X^{2}=1.28$ & $X^{2}=8.05^{* *}$ \\
\hline Prevalence of all gastrointestinal parasites & 92.9 & 87.5 & 74.1 & 78.7 & 83.3 & 0.13 & $p=0.72$ & $x^{2}=1.76$ & 0.65 \\
\hline
\end{tabular}


lence of Subulura sp. and of Coccidia were higher in M5 than in M15 ( $X^{2}=4.43$ and $X^{2}=5.18, d f=1, p<0.05$, respectively; Table 3$)$.

Intensity of infection: Faeces of Microcebus murinus from M5 contained higher concentrations of nematode eggs and larvae, particularly of Subulura sp. and cysts of Coccidia than those of animals from M15 $(z=2.48, p=0.013 ; z=2.20, p=$ $0.028 ; z=3.47, p=0.001$, respectively). Considering the total parasite community, mouse lemurs from M5 showed higher numbers of helminth eggs and larvae plus protozoan cysts than individuals from M15 ( $z=3.55, p<0.001$; Table 4$)$.

Effect of fragment size in degraded forest fragments The effect of forest and population size on parasite loads of Microcebus murinus was compared between the two degraded fragments M20 (small) and M13 (large).

Parasite species richness: The average number of parasites per individual Microcebus murinus did not differ between different sized degraded forest fragments (Figure 2).

Prevalence of parasites: Among the nematodes, only the non-identified species of Oxyuridae differed significantly in their prevalence between M20 and M13, reaching higher prevalence in the smaller fragment (Fisher's exact test: $p=0.023$; Table 3 ).

Intensity of infection: As a logical consequence of the finding that the prevalence of oxyurid nematodes was 0 in $\mathrm{M} 13$, the higher prevalence of the oxyurid nematode in M20 was paralleled by a higher faecal egg and larvae count in this fragment than in M13 ( $z=2.30, p<0.05)$ with a maximum count of 50 eggs and larvae / $g$ faeces in Microcebus murinus from M20 (Table 4).

EFFECT OF FOREST DEGRADATION IN LARGE FOREST FRAG-

MENTS. The effect of forest degradation in large forest fragments was based on the comparison of the parasite loads of Microcebus murinus in M13 (poor quality) and M15 (good quality).

Parasite species richness: Lemurs from the degraded fragment M13 are significantly more often infected by both species of cestodes (Hymenolepis spp.) than animals from the higher quality forest fragment M15 (Mann Whitney $U$ test: $z=3.22, p<0.001)$. Given the uncertainties associated with quantitative analyses of cestodes, this result might need further study.

TABLE 4. Number of parasite eggs and larvae (in case of helminths) or cysts (in case of Protozoa) per gram of faecal materials in $M$. murinus of different fragments. Values are medians; minima and maxima in brackets. Differences between fragments were evaluated with Mann-Whitney $\mathrm{U}$ test; values are $\mathrm{Z}$-values and associated significance: ${ }^{*} p<0.05 ; * * p<0.01 ; * \star * p<0.001$.

\begin{tabular}{|c|c|c|c|c|c|c|c|c|c|}
\hline & \multicolumn{5}{|c|}{ Fragment } & \multicolumn{4}{|c|}{ Comparison } \\
\hline & M5 & M13 & M15 & M16 & M20 & M5 - M15 & M20 - M13 & M15 - M13 & M5 - M20 \\
\hline Number of $M$. murinus & 14 & 24 & 54 & 47 & 30 & & & & \\
\hline \multicolumn{10}{|l|}{ Nemathelminthes } \\
\hline \multicolumn{10}{|l|}{ Ascarididae } \\
\hline \multirow{2}{*}{$\begin{array}{l}\text { Ascarididae } \\
\text { species }\end{array}$} & 0 & 0 & 0 & 0 & 0 & 1 & 0.59 & $2.63^{* *}$ & 0.56 \\
\hline & [0-11900] & [0-25100] & [0-8400] & [0-2850] & [0-12700] & & & & \\
\hline \multirow[t]{2}{*}{ Subulura sp. } & 50 & 0 & 0 & 0 & 0 & $2.20 *$ & 0.4 & 1.41 & $2.68^{* *}$ \\
\hline & {$[0-600]$} & [0-150] & [0-800] & [0-750] & {$[0-550]$} & & & & \\
\hline \multicolumn{10}{|l|}{ Strongylida } \\
\hline \multirow{2}{*}{$\begin{array}{l}\text { Strongylida } \\
\text { species }\end{array}$} & 0 & 0 & 0 & 0 & 0 & 1.3 & 1.28 & 1.69 & 0.98 \\
\hline & {$[0-0]$} & {$[0-0]$} & {$[0-50]$} & {$[0-250]$} & {$[0-50]$} & & & & \\
\hline \multicolumn{10}{|l|}{ Trichuridae } \\
\hline \multirow[t]{2}{*}{ Trichuris sp. } & 0 & 0 & 0 & 0 & 0 & 0.68 & 1.58 & 1.36 & 0.32 \\
\hline & {$[0-50]$} & {$[0-0]$} & {$[0-550]$} & {$[0-0]$} & {$[0-650]$} & & & & \\
\hline \multicolumn{10}{|l|}{ Oxyuridae } \\
\hline \multirow[t]{2}{*}{ Lemuricola sp. } & 0 & 0 & 0 & 0 & 0 & 1.17 & 0.13 & 0.77 & 0.68 \\
\hline & {$[0-0]$} & {$[0-50]$} & {$[0-50]$} & {$[0-0]$} & [0-200] & & & & \\
\hline \multirow[t]{2}{*}{ Oxyuridae species } & 0 & 0 & 0 & 0 & 0 & 0.55 & $2.30 *$ & 0.94 & 1.13 \\
\hline & {$[0-50]$} & {$[0-0]$} & {$[0-50]$} & {$[0-50]$} & [0-150] & & & & \\
\hline \multirow[t]{2}{*}{ All nematodes } & 150 & 0 & 25 & 50 & 75 & $2.48 * *$ & 0.38 & 0.48 & 0.93 \\
\hline & [0-11900] & [0-25150] & [0-9150] & [0-2900] & [0-13150] & & & & \\
\hline \multicolumn{10}{|l|}{ Plathelminthes } \\
\hline \multicolumn{10}{|l|}{ Cestoda } \\
\hline \multicolumn{10}{|l|}{ Hymenolepididae } \\
\hline \multirow[t]{2}{*}{ Hymenolepis sp1 } & 0 & 0 & 0 & 0 & 0 & 1.51 & 0.16 & $2.88^{* *}$ & 0.64 \\
\hline & {$[0-5550]$} & [0-16800] & [0-4500] & [0-59350] & [0-8400] & & & & \\
\hline \multirow[t]{2}{*}{ Hymenolepis sp2 } & 0 & 0 & 0 & 0 & 0 & 0.51 & 0.31 & 1.4 & 0.98 \\
\hline & {$[0-0]$} & [0-3000] & [0-1000] & [0-1000] & {$[0-50]$} & & & & \\
\hline \multirow[t]{2}{*}{ All cestodes } & 0 & 0 & 0 & 0 & 0 & 1.47 & 0.35 & $3.20 * * *$ & 0.81 \\
\hline & [0-5550] & [0-16800] & {$[0-4500]$} & [0-59350] & {$[0-8400]$} & & & & \\
\hline \multirow[t]{2}{*}{ Protozoa (Coccidia) } & 5300 & 75 & 0 & 0 & 0 & $3.47^{* \star *}$ & 1.18 & 1.44 & $3.06 * *$ \\
\hline & [0-687600] & [0-159600] & [0-39400] & [0-525600] & [0-148800] & & & & \\
\hline \multirow{2}{*}{$\begin{array}{l}\text { All parasites (eggs, } \\
\text { larvae and cysts) }\end{array}$} & 9725 & 675 & 200 & 1300 & 200 & $3.55^{* * *}$ & 0.38 & $1.93^{*}$ & $2.50 * *$ \\
\hline & [0-688200] & [0-184750] & [0-39400] & [0-526200] & [0-161950] & & & & \\
\hline
\end{tabular}




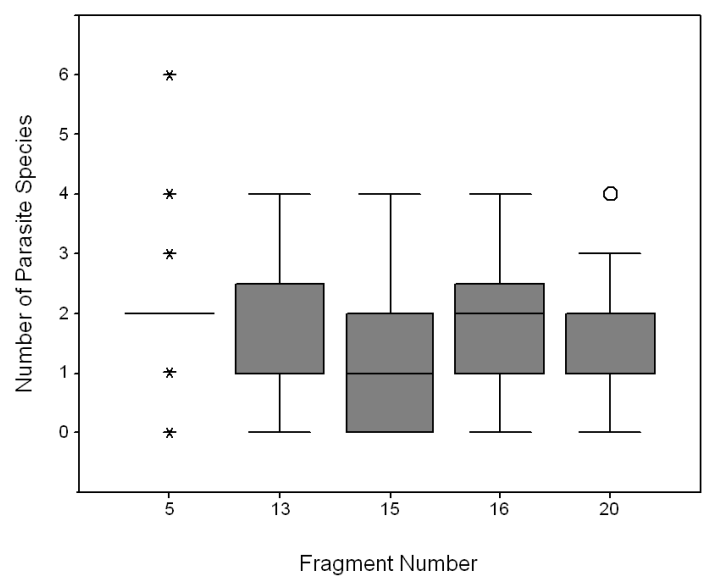

FIGURE 2. Number of gastrointestinal parasite species in individual Microcebus murinus in different forest fragments. Values are medians, quartiles and ranges.

Prevalence of parasites: Among the nematodes, Ascarididae showed higher prevalence in the degraded M13 than in the intact forest of M15 $(p<0.05)$. The cestode community in general and Hymenolepis sp1 in particular were significantly more abundant in M13 than in M15 ( $p<0.05$; Table 3$)$.

Intensity of infection: The higher prevalence of Ascarididae in M13 was associated with higher counts of eggs of this parasite in $M 13$ than in M15 $(z=2.63 ; p<0.01)$. Mouse lemurs from M13 shed significantly more parasite eggs, larvae and cysts than animals from M15 ( $z=1.93, p<0.05)$. Apart from the higher egg counts of Ascarididae, this was due to higher counts of cestode eggs in general, and in particular of Hymenolepis sp1. (all cestodes: $z=$ 3.20, $p=0.001$; Hymenolepis sp1: $z=2.88, p<0.01$; Table 4).

EFFECT OF FOREST DEGRADATION IN SMALL FOREST

FRAGMENTS. The effect of forest degradation in small forest fragments was based on the comparison of the parasite loads of Microcebus murinus in M20 (poor quality) and M5 (good quality).

Parasite species richness: The average number of parasites per individual Microcebus murinus did not differ between small forest fragments with different forest quality (Figure 2).

Prevalence of parasites: The prevalence of Subulura sp. and of Coccidia was significantly higher in the less degraded fragment M5 than in the degraded fragment $M 20\left(X^{2}=9.31\right.$, $p<0.01$ and $X^{2}=8.05, p<0.01$, respectively; Table 3 ).

Intensity of infection (Faecal Egg Count): Again, the difference in prevalence was mirrored by differences in the intensity of infection. These differences were significant for the parasite community in general $(z=2.50, p<0.05)$ as well as for Subulura sp. $(z=2.68, p<0.01)$ and Coccidia $(z=3.06, p<0.01$; Table 4$)$.

\section{DISCUSSION}

Madagascar's forests suffer from fragmentation and degradation (Mittermeier et al. 2004, Elmqvist et al. 2007, Harper et al. 2007, Allnutt et al. 2008). Apart from causing reductions in population size, these processes increase the exposure of native forest animals to more generalized species, which can use the anthropogenic matrix around the remaining fragments and act as vectors for diseases. Despite an early warning of possible negative effects of the infection of native mammals by diseases carried by introduced species (Goodman 1995), little work has been done to assess these effects (Duplantier and Duchemin 2003, Duplantier et al. 2003).

A study on the occurrence of gastrointestinal parasites in a small mammal community of the littoral forest ecosystem showed that rats (Rattus rattus) share many gut parasites with the native small mammal species (Raharivololona et al. 2007). Since rats also use non-forested areas, they can spread parasites from one forest fragment to another. The results of the study illustrated that forest degradation was an important component of disease transmission and favored the spread of diseases. However, sample size was small and statistical significance weak in the previous analysis. Therefore we extended the database. Jovani and Tella (2006) discuss possible problems associated with sample size in parasitological studies. They conclude that a sample size around 15 represents a reasonable number to maintain an acceptable level of uncertainty. Our sample sizes match this recommendation, but we certainly cannot exclude artifacts.

In principle, the results of the previous study were confirmed by the additional data presented here. Lemurs from large fragments (M15 and M13) had lower parasite loads than animals from corresponding smaller fragments (M5 and M20). This also matches the results of studies on mainland Africa where gastrointestinal parasite load of colobus monkeys from Kibale National Park in Uganda was negatively correlated to the size of the forest fragments (Gillespie and Chapman 2006). Despite their lower parasite loads on an individual level, more parasite species were found in the larger fragments as a whole. This may be a consequence of the larger samples of hosts (more individuals) caught in the larger fragments.

The effect of degradation was not so clear. Results from Kibale in Uganda suggest that the prevalence of parasites should be higher in degraded than in non-degraded forests (Gillespie and Chapman 2006). Schwitzer et al. (In press) also reported higher parasite prevalence in Eulemur macaco flavifrons in degraded than in intact forests. This expectation was confirmed when comparing large fragments in Mandena. Here, forest degradation was linked to increased parasite load in the degraded fragment. However, in our study, the result was reversed when comparing degraded and less degraded small fragments. A possible interpretation could be that lemurs in small fragments have more parasites anyhow and that the size effect masks the effect of degradation in small fragments. But then we would expect similar levels of parasitism in both small fragments. The situation might be complicated further by social interactions and population densities. In general, the transmission of diseases increases with the number of social contacts, either due to the animals' social system (e.g., group living) or with increasing population density (Anderson and May 1979, 1991, Freeland 1976, Davies et al. 1991, Phillippi and Clarke 1992, Côté and Poulin 1995, Loehle 1995, Morand 2000, Hudson et al. 2002, Altizer et al. 2003, Nunn et al. 2003). Absolute population densities of Microcebus murinus are unknown for the different fragments, but trapping success was lower in M5 compared to M20, indicating higher population densities in M20 than in M5 (Table 1). This higher population density might have led to higher contact frequencies and thus increased disease transmission between M. murinus in M20 compared to M5. Thus, population characteristics of the host also do not match the expectations. In contrast, lemur densities 
seem to be very similar in M13 and M15 (Ganzhorn et al. 2007) or might be even lower in M13 than in M15 (Table 1). Based on the results from other studies, host density and encounter rates might act as confounding factors. Their consequences for the situation in Mandena remain unknown.

In conclusion, the intensity and prevalence of gastrointestinal parasites of Microcebus murinus are elevated in small forest fragments and seem to increase with the degree of forest degradation in larger fragments. Since mouse lemurs share some of their gastrointestinal parasites with other small mammals, including introduced rats, it is likely that this increased infestation is driven by multiple factors, including fragment size and disturbance. Additionally, local ecological factors such as increased disease transmission through introduced species and crowding effects may also be important factors affecting parasite species richness, prevalence and egg counts.

\section{ACKNOWLEDGMENTS}

The study has been conducted under the Accord de Collaboration between the Université d'Antananarivo (Département de Biologie Animale and Département d'Anthropologie et de Biologie Évolutive) and Hamburg University. It is part of the biodiversity assessment and environmental impact studies of the littoral forest fragments initiated by QIT Madagascar Minerals (QMM). We thank Refaly Ernest for assistance with the fieldwork; Manon Vincelette, Jean-Baptiste Ramanamanjato, and their environmental and conservation team as well as other staff of QMM for technical assistance and help with logistics; Prof. Simone Sommer, Jan Axtner, Yvonne Meyer-Lucht and Nina Schwensow, (now at the Institute for Zoo and Wildlife Research, Berlin), and the staff at the Department of Animal Ecology and Conservation, Hamburg University; Dr. Frédéric Ariey and the Malaria Department of the Institut Pasteur de Madagascar; Dr. Rakotondravao, Gervais Randrianarivo and the Département de Recherches Zootechniques et Vétérinaires / FOFIFA for help and assistance in the laboratory analyses. We also thank Prof. D. W. Büttner (Bernhard Nocht Institute, Hamburg), Prof. Alain G. Chabaud, Dr. Odile Bain, and Dr. Marie-Claude DuretteDesset, Dr. J. P. Hugot (Muséum National d'Histoire Naturelle, Paris), Dr. Thomas R. Gillespie (Dept. Zoology at Florida State University), and Dr. David Modrý (Dept of Parasitology, University of Veterinary and Pharmaceutical Sciences, Czech Republic) for their advice. Patrick Waeber, Lucienne Wilmé and three reviewers provided excellent comments and advice on a previous version of the manuscript. Stephen Nash provided the map. This study was funded by the Margot Marsh Biodiversity Foundation, QMM, the German Research Foundation (DFG, Ga 342 / 14), and the German Academic Exchange Service (DAAD).

\section{REFERENCES}

Allnutt, T. F., Ferrier, S., Manion, G., Powell, G. V. N., Ricketts, T. H., Fisher, B. L., Harper, G. J., Irwin, M. E., Kremen, C., Labat, J.-N., Lees, D. C., Pearce, T. A. and Rakotondrainibe, F. 2008. A method for quantifying biodiversity loss and its application to a 50-year record of deforestation across Madagascar. Conservation Letters 1, 4: 173-181. (doi:10.1111/j.1755263X.2008.00027.X)

Altizer, S., Nunn, C. L., Thrall, P. H., Gittleman, J. L., Antonovics, J., Cunningham, A. A., Dobson, A. P., Ezenwa, V., Jones, K. E., Pedersen, A. B., Poss, M. and Pulliam, J. R. C. 2003. Social organization and parasite risk in mammals: Integrating theory and empirical studies. Annual Reviews in Ecology, Evolution, and Systematics 34: 517-547. (doi:10.1146/annurev. ecolsys.34.030102.151725)
Anderson, R. M. and May, R. M. 1979. Population biology of infectious diseases. Nature 280: 361-367. (doi:10.1038/280361a0)

Anderson, R. M. and May, R. M. 1991. Infectious Diseases of Humans: Dynamics and Control. Oxford University Press, Oxford.

Appleton, C. C., Henzi, S. P., Whitten, A. and Byrne, R. 1986. The gastro-intestinal parasites of Papio ursinus from the Drakensberg Mountains, Republic of South Africa. International Journal of Primatology 7, 5: 449-456. (doi: 10.1007/BF02693656)

Ashford, R. W., Reid, G. D. and Butynski, T. M. 1990. The intestinal faunas of man and mountain gorillas in a shared habitat. Annals of Tropical Medicine and Parasitology 84, 4: 337-340.

Ashford, R. W., Reid, G. D. F. and Wrangham, R. W. 2000. Intestinal parasites of the chimpanzee Pan troglodytes, in Kibale Forest, Uganda. Annals of Tropical Medicine and Parasitology 94, 2: 173-179. (doi:10.1080/000 34980057518)

Begon, M., Hazel, S. M., Baxby, D., Bown, K., Cavanagh, R., Chantrey, J., Jones, T. and Bennett, M. 1999. Transmission dynamics of a zoonotic pathogen within and between wildlife host species. Proceedings of the Royal Society of London, B 266: 1939-1945. (doi:10.1098/rspb.1999.0870)

Bodin, Ö., Tengö, M., Norman, A., Lundberg, J. and Elmqvist T. 2006. The value of small size: loss of forest patches and ecological thresholds in southern Madagascar. Ecological Applications 16, 2: 440-451.

Boyce, M. S. 1990. The red queen visits sage grouse leks. American Zoologist 30, 2: 263-270. (doi:10.1093/icb/30.2.263)

Burney, D. A., Pigott Burney, L., Godfrey, L. R., Jungers, W. L., Goodman, S. M., Wright, H. T. and Jull, A. J. T. 2004. A chronology for late prehistoric Madagascar. Journal of Human Evolution 47: 25-63 (doi:10.1016/ j.jhevol.2004.05.005).

Cassinello, J., Gomendio, M. and Roldan, E. R. S. 2001. Relationship between coefficient of inbreeding and parasite burden in endangered gazelles. Conservation Biology 15, 4: 1171-1174. (doi:10.1046/j.15231739.2001.0150041171.x)

Chabaud, A. G. \& Brygoo, E. R. 1956. Description de Rictularia lemuri n. sp. (Nematoda: Thelaziidae). Mémoires de I'Institut Scientifique de Madagascar 11, série A: 43-49.

Chabaud, A. G. \& Choquet, M. T. 1955. Deux nématodes parasites de lémurien. Annales de Parasitologie 30, 4: 329-338.

Chabaud, A. G. \& Petter, A. J. 1958. Les nématodes parasites de lémuriens malgaches. Mémoires de I'Institut Scientifique de Madagascar 12, série A: $139-158$.

Chabaud, A. G. \& Petter, A. J. 1959. Les nématodes parasites de lémuriens malgaches. II. Un nouvel oxyure: Lemuricola contagiosus. Mémoires de I'Institut Scientifique de Madagasacar 13, série A: 127-132.

Chabaud, A. G., Petter, A. J. \& Golvan, Y. 1961a. Les nématodes parasites de lémuriens malgaches. III. Collection récoltée par M. et Mme Francis Petter. Annales de Parasitologie 36, 1-2: 113-126.

Chabaud, A. G., Brygoo, E. R. \& Petter, A. J. 1961b. Les nématodes parasites de lémuriens malgaches. IV. Description de deux nouveaux genres et observations sur Protofilaria furcata Chandler. Bulletin du Muséum National d'Histoire Naturelle 33, 2e série 5: 532-544.

Chabaud, A. G., Brygoo, E. R. \& Petter, A. J. 1964. Les nématodes parasites de lémuriens malgaches. V. Nématodes de Daubentonia madagascariensis. Vie et Milieu, Suppl. n 17: 205-212.

Chabaud, A. G., Brygoo, E. R. \& Petter, A. J. 1965. Les nématodes parasites de lémuriens malgaches. VI. Description de six espèces nouvelles et conclusions générales. Annales de Parasitologie 40, 2: 181-214.

Chandra, R. K. and Newberne, P. M. 1977. Nutrition, Immunity and Infection Plenum Press, New York.

Chapman, C. and Huffman, M. A. 2009. Primates and their Parasites. Cambridge University Press, Cambridge.

Coltman, D. W., Pilkington, J. G., Smith, J. A. and Pemberton, J. M. 1999. Parasite-mediated selection against inbred Soay sheep in a free-living, island population. Evolution 53, 4: 1259-1267.

Coop, R. L. and Holmes, P. H. 1996. Nutrition and parasite interaction. International Journal for Parasitology 26, 8-9: 951-962. (doi:10.1016/ S0020-7519(96)80070-1)

Côté, I. M. and Poulinb, R. 1995. Parasitism and group size in social animals: a meta-analysis. Behavioral Ecology 6, 2: 159-165. (doi:10.1093/ beheco/6.2.159) 
Davies, C. R., Ayres, J. M., Dye, C. and Deane, L. M. 1991. Malaria infection rate of Amazonian primates increases with body weight and group size. Functional Ecology 5, 5: 655-662.

Despommier, D. D., Gwazda, R. W. and Hotez, P. J. 1995. Parasitic Diseases Springer-Verlag, New York.

Dobson, A. P. and Hudson, P. J. 1992. Regulation and stability of a free-living host-parasite system: Trichostrongylus tenuis in red grouse. II. Population models. Journal of Animal Ecology 61, 2: 487-498.

Duplantier, J.-M. and Duchemin, J.-B. 2003. Human diseases and introduced small mammals. In: The Natural History of Madagascar, S. M. Goodman and J. Benstead (eds.), pp 158-161. The University of Chicago Press, Chicago.

Duplantier, J.-M., Catalan, J., Orth, A., Grolleau, B. and Britton-Davidian, J. 2003. Systematics of the black rat in Madagascar: Consequences for the transmission and distribution of plague. Biological Journal of the Linnean Society 78, 3: 335-341. (doi:10.1046/j.1095-8312.2003.00142. $\mathrm{X})$

Eley, R. M., Strum, S. C., Muchemi, G. and Reid, G. D. F. 1989. Nutrition, body condition, activity patterns and parasitism of free-ranging troops of olive baboons (Papio anubis) in Kenya. American Journal of Primatology 18, 3: 209-219. (doi:10.1002/ajp.1350180304)

Elmqvist, T., Pyykönen, M., Tengö, M., Rakotondrasoa, F., Rabakonandrianina, E. and Radimilahy, C. 2007. Patterns of loss and regeneration of tropical dry forest in Madagascar: The socia institutional context. PIOS ONE 2, 5: e402. (doi:10.1371/journal. pone.0000402)

Euzéby, J. 1981. Diagnostic expérimental des helminthoses animales. Tome 1. Éditions Informations Techniques des Services Vétérinaires, Ministère de I'Agriculture, Paris.

Freeland, W. J. 1976. Pathogens and the evolution of primate sociality. Biotropica 8, 1: 12-24.

Ganzhorn, J. U., Andrianasolo, T., Andrianjazalahatra, T., Donati, G., Fietz, J., Lahann, P., Norscia, I., Rakotondranary, J., Rakotondratsima, B., Ralison, J., Ramarokoto, R. E. A. F., Randriamanga, S., Rasarimanana, S., Rakotosamimanana, B., Ramanamanjato, J.-B., Randria, G. F. N. Rasolofoharivelo, T. M., Razanahoera-Rakotomalala, M. R., Schmid, J. and Sommer, S. 2007. Lemurs in evergreen littoral forest fragments. In: Biodiversity, Ecology, and Conservation of Littoral Forest Ecosystems in Southeastern Madagascar, Tolagnaro (Fort Dauphin). J. U. Ganzhorn, S. M. Goodman and M. Vincelette (eds.), pp 247-258. Smithsonian Institution, Washington D.C.

Ganzhorn, J. U., Hapke, A., Lahann, P., Raharivololona, B. M., Ramanamanjato, J.-B., Refaly, E., Schmid, J., Schad, J. and Sommer, S. In press. Population genetics, parasitism and long-term population dynamics of Microcebus murinus in littoral forest fragments of south-eastern Madagascar. In: Leaping Ahead: Advances in Prosimian Biology, J. Masters, M. Gamba and F. Génin (eds.). Springer Heidelberg.

Gillespie, T. R. and Chapman, C. A. 2006. Prediction of parasite infection dynamics in primate metapopulations based on attributes of forest fragmentation. Conservation Biology 20, 2: 441-448. (doi:10.1111/j.1523-1739.2006.00290.x)

Gillespie, T. R., Greiner, E. C. and Chapman, C. A. 2004. Gastrointestinal parasites of the guenons of western Uganda. Journal of Parasitology 90, 6: 1356-1360. (doi:10.1645/GE-311R)

Gillespie, T. R., Greiner, E. C. and Chapman, C. A. 2005. Gastrointestinal parasites of the colobus monkeys of Uganda. Journal of Parasitology 91, 3: 569-573. (doi:10.1645/GE-434R)

Goodman, S. M. 1995. Rattus on Madagascar and the dilemma of protecting the endemic rodent fauna. Conservation Biology 9, 2: 450-453. (doi:10.1046/j.1523-1739.1995.9020450.x)

Gulland, F. M. D., Albon, S. D., Pemberton, J. M., Moorcroft, P. R. and Clutton-Brock, T. H. 1993. Parasite associated polymorphism in a cyclic ungulate population. Proceedings of the Royal Society of London B 254, 1339: 7-13. (doi:10.1098/rspb.1993.0119)

Hahn, N. E., Proulx, D., Muruthi, P. M., Alberts, S. and Altmann, J. 2003 Gastrointestinal parasites in free-ranging Kenyan baboons (Papio cynocephalus and $P$. anubis). International Journal of Primatology 24 2: 271-279. (doi:10.1023/A:1023092915171)
Hannah, L., Dave, R., Lowry II, P.P., Andelman, S., Andrianarisata, M., Andriamaro, L., Cameron, A., Hijmans, R., Kremen, C., Mackinnon, J., Randrianasolo, H. H., Andriambololonera, S., Razafimpahanana, A., Randriamahazo, H., Randrianarisoa, J., Razafinjatovo, P., Raxworthy, C. Schatz, G. E., Tadross, M. and Wilmé, L. 2008. Climate change adaptation for conservation in Madagascar. Biology Letters 4: 590-594.

Harper, G. J., Steininger, M. K., Tucker, C. J., Juhn, D. and Hawkins, F. 2007. Fifty years of deforestation and forest fragmentation in Madagascar. Environmental Conservation 34: 325-333. (doi:10.1017/ S0376892907004262)

Hochachka, W. M. and Dhondt, A. A. 2000. Density dependent decline of host abundance resulting from a new infectious disease. Proceedings of the National Academy of Science of the United States of America 97, 10: 5303-5306. (doi:10.1073/pnas.080551197)

Hudson, P. J., Dobson, A. P. and Newborn, D. 1992. Do parasites make prey vulnerable to predation: Red grouse and parasites. Journal of Animal Ecology 61, 3: 681-692.

Hudson, P. J., Dobson, A. P. and Newborn, D. 1998. Prevention of population cycles by parasite removal. Science 282, 5397: 2256-2258. (doi:10.1126/science.282.5397.2256)

Hudson, P. J., Rizzoli, A., Grenfell, B. T., Heesterbeek, H. and Dobson, A. P. 2002. The Ecology of Wildlife Diseases. Oxford University Press, Oxford, United Kingdom.

Hugot, J.-P. and Baylac, M. 2007. Shape patterns of genital papillae in pinworms (Enterobiinae, Oxyurida, Nematoda) parasite of primates: A landmark analysis. Infection, Genetics and Evolution 7, 2: 168-179. (doi:10.1016/j.meegid.2006.08.001)

Hugot, J.-P., Morand, S. and Gardner, S. L. 1995. Morphology and morphometrics of three oxyurids parasitic in primates with a description of Lemuricola microcebi n. sp. International Journal for Parasitology 25, 9 : 1065-1075. (doi:10.1016/0020-7519(95)00021-S)

Hugot, J.-P., Gardner, S. L. and Morand, S. 1996. The Enterobiinae subfam. nov. (Nematoda, Oxyurida) pinworm parasites of primates and rodents. International Journal for Parasitology 26, 2: 147-159. (doi:10.1016/0020-7519(95)00108-5)

Irwin, M. T. and Raharison, J.-L. In press. A review of the endoparasites of the lemurs of Madagascar. Malagasy Nature.

Jovani, R. and Tella, J. L. 2006. Parasite prevalence and sample size: misconceptions and solutions. Trends in Parasitology 22, 5: 214-218. (doi:10.1016/j.pt.2006.02.011)

Junge, R. E. and Louis, E. E. 2002. Medical evaluation of free-ranging primates in Betampona reserve, Madagascar. Lemur News 7: 23-25.

Junge, R. E. and Louis, E. E. 2005. Preliminary biomedical evaluation of wild ruffed lemurs (Varecia variegata and $V$. rubra). American Journal of Primatology 66, 1: 85-94. (doi:10.1002/ajp.20129)

Junge, R. E. and Louis, E. E. 2007. Biomedical evaluation of black lemurs (Eulemur macaco macaco) in Lokobe Reserve, Madagascar. Journal of Zoo and Wildlife Medicine 38, 1: 67-76. (doi:10.1638/06-006.1)

Junge, R. E. and Sauther, M. L. 2006. Overview on the health and disease ecology of wildlemurs: Conservation implications. In: Lemurs: Ecology and Adaptation. L. Gould and M. L. Sauther (eds.), pp 423-440. Springer, New York.

Lahann, P., Schmid, J. and Ganzhorn, J. U. 2006. Geographic variation in populations of Microcebus murinus in Madagascar: Resource seasonality or Bergmann's rule? International Journal of Primatology 27, 4 983-999. (doi:10.1007/s10764-006-9055-y)

Lilly, A. A., MehIman, P. T. and Doran, D. 2002. Intestinal parasites in gorillas, chimpanzees, and humans at Mondika Research Site, Dzanga-Ndoki National Park, Central African Republic. International Journal of Primatology 23, 3: 555-573. (doi:10.1023/A:1014969617036)

Loehle, C. 1995. Social barriers to pathogen transmission in wild animal populations. Ecology 76, 2: 326-335. (doi:10.2307/1941192)

Martin, R. D. 1972. A preliminary field study of the lesser mouse lemur (Microcebus murinus J. F. Miller 1777). Zeitschrift für Tierpsychologie 9: 43-89.

McGrew, W. C., Tutin, C. E. G., Collins, D. A. and File, S. K. 1989. Intestinal parasites of sympatric Pan troglodytes and Papio spp. at two sites: Gombe (Tanzania) and Mt. Assirik (Senegal). American Journal of Primatology 17, 2: 147-155. (doi: 10.1002/ajp.1350170204) 
Meyer-Lucht, Y. 2003. Einfluss von Verstädterung auf Populationsstruktur, genetische Variabilität und Parasitenbefall bei der Gelbhalsmaus (Apodemus flavicollis). Diploma thesis, Universität Hamburg, Germany.

Meyer-Lucht, Y. and Sommer, S. 2005. MHC diversity and the association to nematode parasitism in the yellow-necked mouse (Apodemus flavicollis). Molecular Ecology 14, 7: 2233-2243. (doi:10.1111/j.1365294X.2005.02557.x)

Mittermeier, R. A., Langrand, O., Lowry II, P. P., Schatz, G., Gerlasch, J., Goodman, S., Steininger, M., Hawkins, F., Raminosoa, N., Ramilijaona, O., Andriamaro, L., Randrianasolo, H., Rabarison, H. and Rakotobe, Z. L. 2004. Madagascar and the Indian Ocean Islands. In: Hotspots Revisited. R. A. Mittermeier, P. Gil, M. Hoffmann, J. Pilgrim, T. Brooks, C. Goetsch Mittermeier, J. Lamoreux and G. da Fonseca (eds.), pp 138144. Cemex, Mexico.

Mittermeier, R. A., Ganzhorn, J. U., Konstant, W. R., Glander, K. E., Tattersall, I., Groves, C. P., Rylands, A. B., Hapke, A., Ratsimbazafy, J., Mayor, M. I., Louis, E. E. J., Rumpler, Y., Schwitzer, C. and Rasoloarison, R. M. 2008. Lemur diversity in Madagascar. International Journal of Primatology 29: 1607-1656.

Morand, S. 2000. Wormy world: comparative tests of theoretical hypotheses on parasite species richness. In: Evolutionary Biology of Host-Parasite Relationships. R. Poulin, S. Morand and A. Skorping (eds.), pp 63-79. Elsevier, Amsterdam.

Müller-Graf, C. D. M., Collins, D. A., Packer, C. and Woolhouse, M. E. J. 1997. Schistosoma mansoni infection in a natural population of olive baboons (Papio cynocephalus anubis) in Gombe Stream National Park, Tanzania. Parasitology 115: 621-627.

Nunn, C. L., Altizer, S., Jones, K. E. and Sechrest, W. 2003. Comparative tests of parasite species richness in primates. American Naturalist 162, 5: 597-614. (doi:10.1086/378721)

Paterson, S., Wilson, K. and Pemberton, J. M. 1998. Major histocompatibility complex variation associated with juvenile survival and parasite resistance in a large unmanaged ungulate population (Ovis aries L.). Proceedings of the National Academy of Sciences of the United States of America 95, 7: 3714-3719. (doi:10.1073/pnas.95.7.3714)

Petter, A. J., Chabaud, A. G., Delavenay, R. \& Brygoo, E. R. 1972. Une nouvelle espèce de nématode du genre Lemuricola, parasite de Daubentonia madagascariensis Gmelin, et considérations sur le genre Lemuricola. Annales de Parasitologie Humaine et Comparée 47: 391-398.

Petter, J.-J., Albignac, R. \& Rumpler, Y. 1977. Mammifères Lémuriens (Primates Prosimiens). Faune de Madagascar 44. ORSTOM-CNRS, Paris.

Phillippi, K. M. and Clarke, M. R. 1992. Survey of parasites of rhesus monkeys housed in small social groups. American Journal of Primatology 27, 4: 293-302. (doi:10.1002/ajp.1350270407)

Rabenantoandro, J., Randriatafika, F. and Lowry II, P. P. 2007. Floristic and structural characteristics of remnant littoral forest sites in the Tolagnaro area. In: Biodiversity, Ecology and Conservation of Littoral Forest Ecosystems in Southeastern Madagascar, Tolagnaro (Fort Dauphin). J. U. Ganzhorn, S. M. Goodman and M. Vincelette (eds.), pp 65-93. Smithsonian Institution, Washington D. C.

Raharivololona, B. M. 2006. Gastrointestinal parasites of Cheirogaleus spp. and Microcebus murinus in the littoral forest of Mandena, Madagascar. Lemur News 11: 31-35.

Raharivololona, B. M. 2009. L'infestation parasitaire de Microcebus murinus de la forêt littorale de Mandena, Madagascar. Madagascar Conservation and Development 4, 1: 52-62.

Raharivololona, B. M. and Ganzhorn, J. U. In press. Seasonality effects in gastrointestinal parasite excretion by the Gray Mouse Lemur (Microcebus murinus) in littoral forests of Madagascar. Endangered Species Research.

Raharivololona, B. M., Rakotondravao and Ganzhorn, J. U. 2007. Gastrointestinal parasites of small mammals in the littoral forest of Mandena. In: Biodiversity, Ecology and Conservation of Littoral Forest Ecosystems in Southeastern Madagascar, Tolagnaro (Fort Dauphin). J. U. Ganzhorn, S. M. Goodman and M. Vincelette (eds.), pp 247-258. Smithsonian Institution, Washington D. C.

Ramanamanjato, J.-B. and Ganzhorn, J. U. 2001. Effects of forest fragmentation, introduced Rattus rattus and the role of exotic tree plantations and secondary vegetation for the conservation of an endemic rodent and a small lemur in littoral forests of southeastern Madagascar. Animal Conservation 4, 2: 175-183. (doi:10.1017/S1367943001001202)
Randriamiadamanana, M. 1998. Contribution au Diagnostic Coprologique du Parasite Spirocerca lupi chez les Lémuriens du Parc Botanique et Zoologique de Tsimbazaza. Mémoire d'Ingéniorat, École Supérieure des Sciences Agronomiques, Université d'Antananarivo, Madagascar.

Rasambainarivo, F. 2008. Contribution à l'Étude des Parasites des Lémuriens en Captivité: Comparaison entre Deux Parcs Zoologiques. Thèse de doctorat, Faculté de Médecine Vétérinaire, Université d'Antananarivo, Madagascar.

Rasolofoharivelo, M. T. 2007. Human exploitation of forest resources in Mandena in 2000. In: Biodiversity, Ecology and Conservation of Littoral Forest Ecosystems in Southeastern Madagascar, Tolagnaro (Fort Dauphin). J. U. Ganzhorn, S. M. Goodman and M. Vincelette (eds.), pp 59-63. Smithsonian Institution, Washington D. C.

Schad, J., Sommer, S. and Ganzhorn, J. U. 2004. MHC variability of a small lemur in the littoral forest fragments of southeastern Madagascar. Conservation Genetics 5, 3: 299-309. (doi:10.1023/B: COGE.0000031137.50239.d3)

Schad, J., Ganzhorn, J. U. and Sommer, S. 2005. Parasite burden and constitution of major histocompatibility complex in the Malagasy mouse lemur, Microcebus murinus. Evolution 59, 2: 439-450. (doi:10.1554/04-312)

Schwensow, N., Fietz, J., Dausmann, K. H. and Sommer, S. 2007. Neutral versus adaptive genetic variation in parasite resistance: Importance of major histocompatibility complex supertypes in a free-ranging primate. Heredity 99: 265-277. (doi:10.1038/sj.hdy.6800993)

Schwitzer, N., Clough, D., Zahner, H., Kaumanns, W., Kappeler, P. M. and Schwitzer, C. In press. Parasite prevalence in blue-eyed black lemurs (Eulemur flavifrons) in differently degraded forest fragments. Endangered Species Research.

Sloss, M. W., Kemp, R. L. and Zajac, A. M. 1994. Veterinary Clinical Parasitology. Iowa State University Press, Ames.

Smith, K. F., Acevedo-Whitehouse, K. and Pedersen, A. B. 2009. The role of infectious diseases in biological conservation. Animal Conservation 12 1-12. (doi:10.1111/j.1469-1795.2008.00228.x)

Stear, M. J., Bishop, S. C., Doligalska, M., Duncan, J. L., Holmes, P. H., Irvine, J., McCririe, L., McKellar, Q. A., Sinski, E. and Murray, M. 1995. Regulation of egg production, worm burden, worm length and worm fecundity by host responses in sheep infected with Ostertagia circumcincta. Parasite Immunology 17, 12: 643-652. (doi:10.1111/j.1365-3024.1995. tb01010.x)

Stoner, K. E. 1996. Prevalence and intensity of intestinal parasites in mantled howling monkeys (Alouatta palliata) in northeastern Costa Rica: Implications for conservation biology. Conservation Biology 10, 2: 539-546. (doi:10.1046/j.1523-1739.1996.10020539.x)

Stuart, M. D., Greenspan, L. L., Glander, K. E. and Clarke, M. R. 1990. A coprological survey of parasites of wild mantled howling monkeys, Alouatta palliata palliata. Journal of Wildlife Diseases 26, 4: 547-549.

Stuart, M., Pendergast, V., Rumfelt, S., Pierberg, S., Greenspan, L., Glander, K. and Clarke, M. 1998. Parasites of wild howlers (Alouatta spp.). International Journal of Primatology 19, 3: 493-512. (doi:10.1023/ A:1020312506375)

Vincelette, M., Dumouchel, J., Giroux, J. and Heriarivo, R. 2007a. The Tolagnaro (Fort Dauphin) region: A brief overview of the geology, hydrology, and climatology. In: Biodiversity, Ecology and Conservation of Littoral Forest Ecosystems in Southeastern Madagascar, Tolagnaro (Fort Dauphin). J. U. Ganzhorn, S. M. Goodman and M. Vincelette (eds.), pp 9-17. Smithsonian Institution, Washington D. C.

Vincelette, M., Théberge, M. and Randrihasipara, L. 2007b. Evaluation of forest cover at regional and local levels in the Tolagnaro region since 1950. In: Biodiversity, Ecology and Conservation of Littoral Forest Ecosystems in Southeastern Madagascar, Tolagnaro (Fort Dauphin). J. U. Ganzhorn, S. M. Goodman and M. Vincelette (eds.), pp 49-58. Smithsonian Institution, Washington D. C.

Wallis, J. and Lee, D. R. 1999. Primate conservation: The prevention of disease transmission. International Journal of Primatology 20, 6: 803-826. (doi:10.1023/A:1020879700286)

Wright, P. C., Arrigo-Nelson, S. J., Hogg, K. L., Bannon, B., Morelli, T. L., Wyatt, J., Harivelo, A. L. and Ratelolahy, F. 2009. Habitat disturbance and seasonal fluctuations of lemur parasites in the rain forest of Ranomafana National Park, Madagascar. In Primates and their Parasites. C. Chapman and M. A. Huffman (eds.), pp 311-330. Cambridge University Press, Cambridge. 